\title{
Pregnancy in adolescence in Brazil: associated factors with maternal age
}

Thamara de Souza Campos Assis 1

iD https://orcid.org/0000-0001-6207-5962

Katrini Guidolini Martinelli 2

iD https://orcid.org/0000-0003-0894-3241

Silvana Granado Nogueira da Gama 3

iD https://orcid.org/0000-0002-9200-0387

Edson Theodoro dos Santos Neto 4

iD https://orcid.org/0000-0002-7351-7719

1,2,4 Programa de Pós-graduação em Saúde Coletiva. Departamento de Medicina Social. Universidade Federal do Espírito Santo. Av. Marechal Campos, 1468. Maruípe. Vitória, ES, Brasil. CEP: 29.040-090. E-mail: thamarasc@yahoo.com.br

3 Escola Nacional de Saúde Pública Sérgio Arouca. Fundação Oswaldo Cruz. Rio de Janeiro, RJ, Brasil.

\begin{abstract}
Objectives: describing maternal characteristics, risk behavior, obstetric data, prenatal care and childbirth in adolescent mothers in Brazil (age groups: 12-16 years and 17-19 years).

Methods: hospital-based cross-sectional study substantiated by Nascer no Brasil”, (Born in Brazil) data. The study encompassed puerperal adolescent mothers from all regions in the country, and their newborns. Chi-square test was used to compare adolescents in the 12-16 years old age group and those in the 17-19 years old age group.

Results: pregnant women in the 12-16 years old age group mostly lived in the Northeast of Brazil $(p=0.014)$; most of them did not have a partner $(p<0.001)$, unplanned pregnancy $(p<0.001)$, they had inadequate schooling for their age $(p=0.033)$, had less than six prenatal consultations $(p=0.021)$, were subjected to episiotomy $(p=0.042)$ and accounted for the largest number of premature babies $(p=0.014)$

Conclusions: puerperal women in the 12-16 years old age group presented vulnerability in their socioeconomic conditions, inadequate assistance at the prenatal and childbirth care, as well as their babies showed neonatal complications that pointed towards these adolescent mothers' need of multidisciplinary care.
\end{abstract}

Key words Pregnancy in adolescence, Prenatal care, Childbirth, Risk behaviors

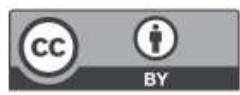




\section{Introduction}

Pregnancy at adolescence remains a relevant topic in the Brazilian ${ }^{1}$ reproductive health scope given its high prevalence, and because it is one of the main causes of morbidity in women in this age group. ${ }^{2}$ According to the World Health Organization (WHO), Brazil accounts for one of the highest rates in pregnancy at adolescence in Latin America, although, it has presented a decrease in the last few years; however, the country recorded 68.4 live born babies for every one thousand girls in the 15-19 years old age group, in 2016.3

Almost $20 \%$ of all births in Brazil, in 2010, were of adolescent mothers, whereas this rate was $14.72 \%$, in 2019 . The most significant reduction in this rate was observed in the 15-19 years old age group. The youngest adolescents (10-14 years) presented rates lower than $1 \%$, and a tendency of a slight reduction. ${ }^{4}$

Pregnant adolescents use to have more inappropriate access to prenatal assistance; they tend to start late prenatal care and to have a smaller number of consultations than adult pregnant women.5,6 Brazil, similar to other countries, also registers high probability of premature childbirth, low birth weight, and maternal and neonatal mortality in adolescent mothers. 7,8 The chance to have other complications during pregnancy, such as urinary infections, abortion, pre-eclampsia, pregnancy-associated hypertensive disease and premature rupture of the membranes are also high. ${ }^{9-11}$

Studies have corroborated that womenin the 16years old age group, or older, have obstetric behavior similar to adult women; therefore, they have less unfavorable neonatal and maternal outcomes than the young ones.5,12 Thus, the aim of this present study is to describe maternal characteristics, risk behaviors, obstetric data, prenatal and childbirth data in puerperal adolescents in Brazil, in the 12-16 years old and 17-19 years old age groups.

\section{Methods}

A cross-sectional study adopted to analyze data collected through the hospital-based national survey known as "Nascer no Brasil", (Born in Brazil), from February 2011 to October 2012. The sample comprises puerperal mothers and their newborns selection was divided into three stages. The first stage included hospitals with more than 500 births/year, which were stratified based on the macro-regions in the country (North, South, Northeast, Southeast and Midwest), the location (state capitals or countryside) and type of service (public, private or mixed). The number of days necessary to interview 90 puerperal women in each one of the 266 previously selected hospitals was defined at the second stage (at least 7 days), based on the reverse sampling method and the third stage puerperal women and their babies were selected. 13

All puerperal women in the 20 years old or younger age group were taken into consideration for this analysis. Information was collected from interviews conducted with the participants during hospitalization, through electronic questionnaire and through data on their prenatal cards - which were photographed and transcribed into the standard form -, as well as through the information in the maternal and neonatal medical records. Medical records were collected after women were discharged, or on the 42nd day of hospitalization / and/or after newborns were discharged, or on the $28^{\text {th }}$ day of the newborns' hospitalization. 14

Maternal schooling (adequate/inadequate for the adolescents' age), economic classification based on the Associação Brasileira de Institutos de Pesquisa de Mercado (Brazilian Association of Market Research Institutes) (economic classes A/B - high, C - middle, D/E - low), self-referred race/skin color (white, black, mixed Asian descendant and indigenous), pre-gestational Body Mass Index (BMI) $\mathrm{Kg} / \mathrm{m}^{2}$ (<18.5 -low weight; 18.5-24.9 - normal; 25.0-29.9 - overweight; 30.0 or more - obese), location of residence (North, Northeast, Southeast, South and Midwest), marital status (without and with a partner) and paying job (yes and no) were used as sociodemographic variables. Smoking during pregnancy (yes and no) and suspicion of inadequate alcohol intake (yes, when women scored two points, or more, within the total of seven points, based on the instrument known as Tolerance, Worried, Eye-opener, Amnesia, K-Cut Down (TWEAK), and no, when they did not have alcoholic drinks during pregnancy or scored only one point) were taken into account to assess maternal risk behavior. 15

Variables related to prenatal care and childbirth were prenatal location (only public /some private consultations / no prenatal care), the same professional assisted throughout the prenatal care and at childbirth (yes/no), type of childbirth financing (public/private), childbirth pilgrimage - was not assisted at the first maternity hospital for childbirth (yes/no) and type of childbirth (vaginal /cesarean section). Episiotomy, perineal laceration and Kristeller's maneuver - all in the yes/no category were also variables assessed for the group of women 
who had vaginal childbirth

Prenatal care was assessed based on the recommendations by the Health Ministry. 16 The trimester pregnancy cycles were considered as reference for the beginning of care provided for the pregnant women (1 st trimester/2nd trimester/3rd trimester/ no prenatal care ), total number of consultations registered on the pregnant women's medical card (less than 6 consultations/ 6 consultations or more/ no prenatal care), prenatal adjustment based on the number of expected consultations for the gestational age (inadequate/ partially adequate/adequate/more than adequate) and performed at least one of the following normal prenatal exams: serology for syphilis, fasting glucose, urine, serology for Human Immunodeficiency Virus (HIV) and ultrasound, were taken into consideration.

Pre-gestational diseases such as high blood pressure, diabetes and heart diseases were included in the study. The following pregnancy complications were: hypertensive diseases (chronic high blood pressure, pre-eclampsia, eclampsia or HELLP syndrome), diabetes, urinary infection, placenta previa, placental abruption and syphilis - all of them were classified as present or absent. As for obstetric history, Cesarean section, abortion, prematurity and low birth weight history were also classified as present and absent.

Besides maternal complications, there were also some neonatal complications in adolescence pregnancy, such as low birth weight $(\leq 2.500 \mathrm{~kg})$ and gestational age at childbirth - spontaneous and induced prematurity (lower than 37 weeks); spontaneous and induced early term (between 37 and 38 weeks); at term (39 to 41 weeks) were classified as present or absent. All analyses were carried out based on age, which was categorized into 12-16 and 17-19 years old. Cutoff point was defined based on some studies, according to, women older than 16 years old have obstetric development similar to adult women. 5,12

Bivariate inferential analysis was adopted tossess the ratio of differences between groups and prenatal socioeconomic characteristics, childbirth, pre-gestational diseases and obstetric history. Chisquare test, with Rao-Scott adjustments, were s carried out to compare nominal variables at $5 \%$ significance level $(p<0.05)$.

The complex sampling design was taken into account throughout the statistical analysis. Besides, each selection stratum was subjected to one calibration procedure due to the basic sampling weights. This was performed to ensure that puerperal women's distribution was similar to those observed for births of the population sampled back in 2011, namely by deriving weighted percentages.

The research was approved by the Research Ethics Committee of the Escola Nacional de Saúde Pública da Fundação Oswaldo Cruz, under the number 92/2010. The digital consent form was signed by each puerperal woman after they read it before the interview. The secondary analysis of gathering data was approved by the Research Ethics Committee of the Centro de Ciências da Saúde da Universidade Federal do Espírito Santo, under the number 3.565.689/2019.

\section{Results}

In total, 4,571 puerperal adolescents at a minimum age of 12 years old participated in this study, 1,375 adolescents in the 12-16 years old age group and 3,196 in the 17-19 years old age group.

In regards to maternal characteristics and risk behavior, most adolescents belonged to the $\mathrm{C}$ economic class (means), they had inadequate schooling for their age and lived with their partners. The comparison between the 12-16 age group and the 17-19 was possible to observe that younger adolescents presented higher inadequate schooling rates $(p=0.033)$, low BMI weight $(p=0.014)$, lived in the Northeast region $(p=0.014)$, did not have a partner and did not have a paying job $(p=0.014)$ (Table 1)

Most adolescents only received prenatal care at the public health centers; they were not examined by the same professional during the prenatal care and at childbirth. Prenatal care in the beginning occurred in the same rate on the $1^{\text {st }}$ and $2^{\text {nd }}$ trimesters; adolescents were assisted 6 or more consultations. HIV, syphilis, Abnormal Sediment Elements (ASE) and fasting blood glucose examination rates ranged from $55.4 \%$ to $63.2 \%$, based on the pregnant women's medical cards. Only $5.4 \%$ of the registered childbirths occurred in private maternity hospitals and $62.9 \%$ were vaginal childbirth. Yet, it was possible to observe that puerperal adolescents 12-16 years old presented the highest rates of 'less than 6 prenatal consultations' $(p=0.021)$, as well as prenatal care inadequacy $(p=0.006)$, childbirth pilgrimage $(p=0.041)$ and episiotomy $(p=0.042)$. On the other hand, women 17-19 years old showed higher perineal laceration rates $(p=0.015)$ (Table 2$)$

Overall, when it comes to obstetric history, and maternal and neonatal complications, adolescents were primiparous and did not plan to be pregnant; urinary infection was the most common complication. The comparison of the two groups allowed to 
observe that the youngest adolescents were accounted for frequently being primiparity $(p<0.001)$, non-intentional pregnancy $(p<0.001)$ and spontaneous prematurity $(p=0.014)$. The oldest adolescents, registered having the highest frequency in previous abortion $(p<0.001)$, history of low birth weight and prematurity $(p<0.001)$, previous Cesarean sections $(p<0.001)$ (Table 3$)$.

Table 1

Analysis of maternal characteristics and risk behavior in puerperal adolescents, "Nascer no Brasil" (Born in Brazil). Brazil, 2011-12.

\begin{tabular}{|c|c|c|c|c|c|c|c|}
\hline \multirow[t]{2}{*}{ Variables } & \multicolumn{2}{|c|}{$\begin{array}{c}\text { Total } \\
(\mathrm{N}=4,571)\end{array}$} & \multicolumn{2}{|c|}{$\begin{array}{c}12-16 \text { years old } \\
(\mathrm{N}=1,375)\end{array}$} & \multicolumn{2}{|c|}{$\begin{array}{c}17-19 \text { years old } \\
(\mathrm{N}=3,196)\end{array}$} & \multirow[t]{2}{*}{$p$} \\
\hline & $\mathrm{n}$ & $\%$ & $\mathrm{n}$ & $\%$ & $\mathrm{n}$ & $\%$ & \\
\hline \multicolumn{8}{|l|}{ Maternal characteristics } \\
\hline Schooling $(n=4,362)$ & & & & & & & 0.033 \\
\hline Adequate for the age & 1,569 & 36.0 & 437 & 33.9 & 1,132 & 36.8 & \\
\hline Inadequate for the age & 2,793 & 64.0 & 853 & 66.1 & 1,940 & 63.2 & \\
\hline Economic classification $(n=4,535)$ & & & & & & & 0.097 \\
\hline Class $\mathrm{D}+\mathrm{E}$ & 1,576 & 34.8 & 529 & 38.9 & 1,047 & 33.0 & \\
\hline Class C & 2,465 & 54.3 & 709 & 52.1 & 1,757 & 55.3 & \\
\hline Class $A+B$ & 494 & 10.9 & 123 & 9.0 & 372 & 11.7 & \\
\hline Skin color $(n=4,570)$ & & & & & & & 0.434 \\
\hline White & 1,242 & 27.2 & 349 & 25.4 & 893 & 27.9 & \\
\hline Black & 405 & 8.9 & 121 & 8.8 & 283 & 8.9 & \\
\hline Mixed & 2,847 & 62.3 & 874 & 63.6 & 1,973 & 61.8 & \\
\hline Asian Descendant & 45 & 1.0 & 15 & 1.1 & 30 & 0.9 & \\
\hline Indigenous & 31 & 0.7 & 15 & 1.1 & 16 & 0.5 & \\
\hline Pre-gestational BMI $\left(\mathrm{Kg} / \mathrm{m}^{2}\right)(\mathrm{n}=4,537)$ & & & & & & & 0.014 \\
\hline$<18.5$ & 395 & 8.7 & 143 & 10.5 & 252 & 7.9 & \\
\hline $18.5-24.9$ & 2,768 & 61.0 & 824 & 60.4 & 1,944 & 61.3 & \\
\hline $25.0-29.9$ & 962 & 21.2 & 303 & 22.2 & 659 & 20.8 & \\
\hline$\geq 30$ & 412 & 9.1 & 95 & 7.0 & 318 & 10.0 & \\
\hline Region $(n=4,571)$ & & & & & & & 0.014 \\
\hline North & 614 & 13.4 & 175 & 12.7 & 438 & 13.7 & \\
\hline Northeast & 1,467 & 32.1 & 511 & 37.2 & 957 & 29.9 & \\
\hline Southeast & 1,686 & 36.9 & 469 & 34.1 & 1,217 & 38.1 & \\
\hline South & 493 & 10.8 & 133 & 9.7 & 360 & 11.3 & \\
\hline Midwest & 311 & 6.8 & 87 & 6.3 & 224 & 7.0 & \\
\hline Marital status $(n=4,568)$ & & & & & & & $<0.001$ \\
\hline Without a partner & 1,435 & 31.4 & 529 & 38.6 & 905 & 28.3 & \\
\hline With a partner & 3,133 & 68.6 & 843 & 61.4 & 2,290 & 71.7 & \\
\hline Paying job $(n=4,568)$ & & & & & & & $<0.001$ \\
\hline Yes & 538 & 11.8 & 56 & 4.1 & 482 & 15.1 & \\
\hline No & 4,030 & 88.2 & 1317 & 95.9 & 2,713 & 84.9 & \\
\hline \multicolumn{8}{|l|}{ Risk behaviors } \\
\hline Smoking during pregnancy $(n=4,568)$ & & & & & & & 0.007 \\
\hline Yes & 394 & 8.6 & 90 & 6.6 & 305 & 9.5 & \\
\hline No & 4,174 & 91.4 & 1284 & 93.4 & 2,891 & 90.5 & \\
\hline \multicolumn{8}{|l|}{ Inappropriate alcohol intake during } \\
\hline pregnancy $(n=4,451)$ & & & & & & & 0.322 \\
\hline Yes & 505 & 11.3 & 132 & 9.9 & 373 & 12.0 & \\
\hline No & 3,946 & 88.7 & 1204 & 90.1 & 2,742 & 88.0 & \\
\hline
\end{tabular}


Table 2

Analysis of maternal characteristics and risk behavior in puerperal adolescents, "Nascer no Brasil"(Born in Brazil). Brazil, 2011-12.

\begin{tabular}{|c|c|c|c|c|c|c|c|}
\hline \multirow[t]{2}{*}{ Variables } & \multicolumn{2}{|c|}{$\begin{array}{c}\text { Total } \\
(\mathrm{N}=4,571)\end{array}$} & \multicolumn{2}{|c|}{$\begin{array}{c}12-16 \text { years old } \\
(\mathrm{N}=1,375)\end{array}$} & \multicolumn{2}{|c|}{$\begin{array}{l}\text { 17-19 years old } \\
(\mathrm{N}=3,196)\end{array}$} & \multirow[t]{2}{*}{$p$} \\
\hline & $\mathrm{n}$ & $\%$ & $\mathrm{n}$ & $\%$ & $\mathrm{n}$ & $\%$ & \\
\hline \multicolumn{8}{|l|}{ Prenatal care characteristics } \\
\hline Prenatal care location $(n=4,555)$ & & & & & & & 0.091 \\
\hline Only public & 4,037 & 88.3 & 1,238 & 90.0 & 2,799 & 87.6 & \\
\hline Some private consultations & 455 & 9.9 & 109 & 7.9 & 345 & 10.8 & \\
\hline No prenatal care & 63 & 1.4 & 20 & 1.5 & 43 & 1.3 & \\
\hline \multicolumn{8}{|l|}{ The same professional at prenatal care and } \\
\hline childbirth $(n=4,567)$ & & & & & & & 0.199 \\
\hline Yes & 341 & 7.5 & 90 & 6.6 & 251 & 7.9 & \\
\hline No & 4,226 & 92.5 & 1,283 & 93.4 & 2,943 & 92.1 & \\
\hline Beginning of prenatal care $(n=4,518)$ & & & & & & & 0.149 \\
\hline 1st trimester & 2,122 & 46.4 & 576 & 41.9 & 1,546 & 48.4 & \\
\hline 2nd trimester & 2,117 & 46.3 & 681 & 49.5 & 1,436 & 44.9 & \\
\hline 3rd trimester & 216 & 4.6 & 78 & 5.7 & 138 & 4.3 & \\
\hline No prenatal care & 63 & 1.4 & 20 & 1.5 & 43 & 1.3 & \\
\hline Number of consultations $(n=4,495)$ & & & & & & & 0.021 \\
\hline Less than 6 consultations & 1,692 & 39.0 & 587 & 43.2 & 1,104 & 35.1 & \\
\hline More than 6 consultations & 2,741 & 61.0 & 750 & 55.3 & 1,990 & 63.4 & \\
\hline No prenatal care & 62 & 1.4 & 20 & 1.5 & 43 & 1.4 & \\
\hline Prenatal care adequacy $(n=4,454)$ & & & & & & & 0.006 \\
\hline Inadequate/partially adequate & 2,105 & 47.3 & 711 & 53.0 & 1,394 & 44.8 & \\
\hline Adequate/more than adequate & 2,349 & 52.7 & 630 & 47.0 & 1,719 & 55.2 & \\
\hline \multicolumn{8}{|l|}{ Registered on the examination card } \\
\hline Blood glucose & 2,739 & 59.9 & 786 & 57.2 & 1,953 & 61.1 & 0.052 \\
\hline ASE & 2,799 & 61.2 & 825 & 60.0 & 1,974 & 61.7 & 0.528 \\
\hline Syphilis & 2,887 & 63.2 & 842 & 61.2 & 2,045 & 64.0 & 0.183 \\
\hline HIV & 2,534 & 55.4 & 737 & 53.6 & 1,797 & 56.2 & 0.342 \\
\hline Underwent obstetric ultrasound $(n=4,553)$ & & & & & & & 0.072 \\
\hline Yes & 4,361 & 95.4 & 1,294 & 94.0 & 3,067 & 96.0 & \\
\hline No & 129 & 2.8 & 52 & 3.8 & 77 & 2.4 & \\
\hline No prenatal care & 63 & 1.4 & 20 & 1.5 & 43 & 1.3 & \\
\hline \multicolumn{8}{|l|}{ Labor characteristics } \\
\hline Type of childbirth financing $(n=4,571)$ & & & & & & & 0.942 \\
\hline Public & 4,325 & 94.6 & 1,302 & 94.7 & 3,023 & 94.6 & \\
\hline Private & 246 & 5.4 & 73 & 5.3 & 173 & 5.4 & \\
\hline Childbirth pilgrimage $(n=4,564)$ & & & & & & & 0.041 \\
\hline Yes & 973 & 21.3 & 319 & 23.2 & 655 & 20.5 & \\
\hline No & 3,591 & 78.7 & 1,053 & 76.7 & 2,538 & 79.5 & \\
\hline Childbirth type $(n=4,571)$ & & & & & & & 0.085 \\
\hline Vaginal / Forceps & 2,875 & 62.9 & 896 & 65.2 & 1,978 & 61.9 & \\
\hline Cesarean section & 1,696 & 37.1 & 478 & 34.8 & 1,218 & 38.1 & \\
\hline Episiotomy* $(n=2,873)$ & & & & & & & 0.042 \\
\hline Yes & 1,609 & 35.2 & 543 & 39.5 & 1,066 & 33.4 & \\
\hline No & 1,264 & 27.7 & 354 & 25.7 & 910 & 28.5 & \\
\hline Perineal Laceration* $(n=2,873)$ & & & & & & & 0.015 \\
\hline Yes & 616 & 21.4 & 162 & 18.1 & 454 & 23.0 & \\
\hline No & 2,257 & 78.6 & 735 & 81.9 & 1,522 & 77.0 & \\
\hline Kristeller maneuver* $(n=2,873)$ & & & & & & & 0.552 \\
\hline Yes & 96 & 3.3 & 26 & 2.9 & 70 & 3.5 & \\
\hline No & 2,777 & 96.7 & 871 & 97.1 & 1,906 & 96.5 & \\
\hline
\end{tabular}

*Only for women who had vaginal childbirth. 
Analysis of obstetric history, and maternal and neonatal complications, "Nascer no Brasil"(Born in Brazil). Brazil, 201112.

\begin{tabular}{|c|c|c|c|c|c|c|c|}
\hline \multirow[t]{2}{*}{ Variables } & \multicolumn{2}{|c|}{$\begin{array}{l}\text { Total } \\
(\mathrm{N}=4,571)\end{array}$} & \multicolumn{2}{|c|}{$\begin{array}{l}12-16 \text { years old } \\
(N=1,375)\end{array}$} & \multicolumn{2}{|c|}{$\begin{array}{c}17-19 \text { years old } \\
(\mathrm{N}=3,196)\end{array}$} & \multirow[t]{2}{*}{$p$} \\
\hline & $\mathrm{n}$ & $\%$ & $\mathrm{n}$ & $\%$ & $\mathrm{n}$ & $\%$ & \\
\hline \multicolumn{8}{|l|}{ Obstetric history } \\
\hline Number of pregnancies $(n=4,570)$ & & & & & & & $<0.001$ \\
\hline Primiparous & 3,721 & 81.4 & 1,285 & 93.5 & 2,436 & 76.2 & \\
\hline$\geq 2$ pregnancies & 849 & 18.6 & 90 & 6.6 & 760 & 23.9 & \\
\hline Intention to get pregnant $(n=4,539)$ & & & & & & & $<0.001$ \\
\hline Yes & 1,574 & 34.7 & 407 & 29.9 & 1,167 & 36.7 & \\
\hline No & 2,965 & 65.3 & 953 & 70.0 & 2,011 & 63.3 & \\
\hline \multicolumn{8}{|l|}{ Pre-existing diseases } \\
\hline Pre-gestational high blood pressure & 83 & 1.8 & 29 & 2.1 & 54 & 1.7 & 0.572 \\
\hline Pre-gestational diabetes & 26 & 0.6 & 10 & 0.7 & 16 & 0.5 & 0.400 \\
\hline Heart diseases & 15 & 0.3 & 5 & 0.4 & 10 & 0.3 & 0.864 \\
\hline \multicolumn{8}{|l|}{ Previous obstetric history } \\
\hline Abortion & 360 & 7.9 & 61 & 4.4 & 299 & 9.4 & $<0.001$ \\
\hline Low birth weight & 114 & 2.5 & 11 & 0.8 & 103 & 3.2 & $<0.001$ \\
\hline Prematurity & 94 & 2.1 & 11 & 0.8 & 83 & 2.6 & $<0.001$ \\
\hline Cesarean section & 292 & 6.4 & 39 & 2.8 & 253 & 7.9 & $<0.001$ \\
\hline \multicolumn{8}{|l|}{ Maternal complications } \\
\hline Urinary infection & 724 & 15.8 & 219 & 15.9 & 505 & 15.8 & 0.953 \\
\hline Hypertensive disease in pregnancy & 338 & 7.4 & 87 & 6.3 & 251 & 7.9 & 0.079 \\
\hline Placenta previa & 11 & 0.2 & 4 & 0.3 & 7 & 0.2 & 0.840 \\
\hline Gestational diabetes & 205 & 4.5 & 54 & 3.9 & 151 & 4.7 & 0.269 \\
\hline Eclampsia & 24 & 0.5 & 9 & 0.7 & 15 & 0.5 & 0.616 \\
\hline Placental abruption & 49 & 1.1 & 20 & 1.5 & 29 & 0.9 & 0.243 \\
\hline Syphilis & 41 & 0.9 & 8 & 0.6 & 33 & 1.0 & 0.128 \\
\hline \multicolumn{8}{|l|}{ Neonatal complications } \\
\hline Low birth weight & 461 & 10.2 & 141 & 10.4 & 320 & 10.1 & 0.712 \\
\hline Gestational age $(n=4,571)$ & & & & & & & 0.014 \\
\hline Spontaneous prematurity & 464 & 10.2 & 183 & 13.3 & 281 & 8.8 & \\
\hline Obstetric intervention prematurity & 133 & 2.9 & 34 & 2.5 & 99 & 3.1 & \\
\hline Spontaneous early term & 1,037 & 22.7 & 310 & 22.5 & 727 & 22.7 & \\
\hline Intervention early term & 396 & 8.7 & 117 & 8.5 & 279 & 8.7 & \\
\hline At term & 2,541 & 55.6 & 731 & 53.2 & 1,810 & 56.6 & \\
\hline
\end{tabular}

\section{Discussion}

The proportion rate of adolescents in "Nascer no Brasil" (Born in Brazil) sample reached 19.1\%.17 The percentage rate of adolescence pregnancy in Brazil in comparison to the total number of births has been decreasing: $19.3 \%$ in 2010 and $17.5 \%$ in 2016; however, its distribution is unequal around the country. 18 A geo-processing study that has analyzed adolescence pregnancy's spatial variation in Brazil has evidenced that the North, Northeast and Midwest regions account for the highest adolescence fertility medians for women in 15-19 years old group (93.5/1,000, 73.1/1,000 and 69.3/1,000, respectively), as well as the highest number of adolescence mothers whose schooling is lower than 
eight years. 19

These findings result to the fact that the fertility rate in adolescents is opposite to their schooling levels. A study carried out in Rio de Janeiro with 59,600 live births of adolescent and young adult women has pointed out that got pregnant and presented inadequate schooling had higher chances in getting pregnant again $(\mathrm{RR}=2.1$; CI95\% $=1.8$ 2.4). 20 Pregnant adolescents who have history of violence presented the lowest schooling, the highest school dropout and the lowest family income levels, as well as lack of short-term life projects. Although, these adolescents, even with the mean age being higher than non-pregnant adolescents, were behind in schooling $(p<0.01)$, only $20 \%$ of them were stil going to school. 21

In total, $70 \%$ of the pregnant women younger than 18 years old in the countryside of Goiás State have the lowest socioeconomic level, $30 \%$ were single, $88 \%$ were unemployed and $75 \%$ did not plan in getting pregnant.22 Girls in African and Asian countries, who were not in school, presented close association with sexual initiation, pregnancy and early marriage. $23-25$ All these vulnerable factors need to the worked at schools, health services and by the community, so that pregnancy at adolescence could be avoided. ${ }^{3}$

A community intervention strategy in India was placed by information centers for adolescents of both sexes, ages between 10-24 years old, has significant reduction effect on both early marriage $(\mathrm{OR}=2.25$; CI95\% $=1.2-3.9)$ and early pregnancy $(\mathrm{OR}=3.0 ; \mathrm{CI} 95 \%=1.0-8.4)$, and an increasing number of adolescents in school $(\mathrm{OR}=2.96$; CI95\%=2.0-4.3). ${ }^{25}$ An intervention study carried out with adolescents in Zambia, ${ }^{23}$ which was part of a randomized study focused on Girls Empowerment, known as RISE, has shown that sexual and reproduction education programs based on participatory focus groups, and on orientation about birth control methods, are effective in reducing unplanned pregnancy.

Less than $10 \%$ of the adolescents reported to have smoked during pregnancy, mainly the ones in the 17-19 years old age group. Studies performed in Piracicaba (Brazil) and in Bradford (England) have found association between pregnant adolescents and smoking during pregnancy in comparison to adult women. Tobacco use during pregnancy can lead to placental malformation and increase the chances of both prematurity and low birth weight. 8,26

Factors such as inadequate pre-gestational BMI, malnutrition in adolescents in the 12-16 years old age group and overweight in pregnant women in the
17-19 years old age group can also contribute to negative outcomes in babies. On the other hand, adolescents presenting adequate pre-gestational weight demonstrate better neonatal outcomes, such as adequate birth weight ( $p=0.018$ ), as observed in a research carried out at a public maternity hospital in Rio de Janeiro, with 542 puerperal adolescents. ${ }^{2}$

A meta-analysis that encompassed studies, whose first childbirth regarded to young mothers at young gynecologic age ( $\leq 2$ years since menarche) or at chronological age ( $\leq 16$ years), have associated maternal nutrition variables (anemia, pre/post gestational weight and anthropometric measurements) to neonatal outcomes (low birth weight, very low birth weight and premature childbirth). The youngest mothers, mainly the 16 years old ones, have higher chances in negative prenatal outcomes such as prematurity $\quad(\mathrm{OR}=1.68 ; \quad \mathrm{CI} 95 \%=1.34-2.11) .{ }^{5}$ Adolescent women in Bradford, England, showed higher chances in extremely early childbirth (at gestational age $<28$ weeks) than adult women $(\mathrm{OR}=5.06 ; \mathrm{CI} 95 \%=1.23-20.78) .26$

Prematurity was most often spontaneous, as reported by Almeida (2018). Young adolescents (1216 years) presented the highest chances of spontaneous prematurity in comparison to older adolescents $(\mathrm{OR}=1.49 ; \mathrm{CI} 95 \%=1.07-2.06)$ and young adult women $(\mathrm{OR}=2.38 ; \mathrm{CI} 95 \%=1.82-3.12) .{ }^{9} \mathrm{~A}$ study conducted in Maringá City, RS - Brazil, presented a growing trend of premature childbirths (gestational age lower than 37 weeks) by puerperal adolescents between 2013-2015.27 A likely explanation to such a finding lies on the fact that adolescent mothers' babies can show such an outcome due to fetus/mother competition for nutrients. 5

The Ministry of Health highlights that women must attend to at least 6 prenatal consultations. Furthermore, early adhesion to prenatal care (in the first trimester of pregnancy) reduces the chances of maternal and neonatal morbidities. ${ }^{4}$ However, adolescents, mainly the youngest ones, can delay the beginning of prenatal care and have inadequate prenatal care due to late pregnancy diagnosis, uncertainties Inaccepting the pregnancy, lack of support and/or difficulty in the relationship with family members and/or with the baby's father. Furthermore, these adolescents have to deal with the obstacles to access the public health systems, mainly due to social and economic reasons. 6,12

Birth pilgrimage, which is an indicator to the lack of quality in care for the pregnant women, was associated with the youngest mothers; which can cause unfavorable outcomes. A study carried out in mid- and small-size cities in Vale do Jequitinhonha 
(MG, Brazil), and in the Northeast and North regions of the country, has shown no association between maternity during prenatal care and child death $(\mathrm{OR}=1.28$; $\mathrm{CI} 95 \%=1.02-1.61) .28$

Vaginal birth was the most frequent among puerperal adolescents $(62.9 \%)$, percentage considered to be low, since WHO states that there is no maternal and neonatal morbidity reduction when Cesarean section rates are higher than $15 \% .1$ Scientific evidences have shown that unnecessary Cesarean sections must be avoided, mainly among primiparous, low-risk women, with babies at term baby in a cephalic position, as well as adolescents, since there are higher chances of Cesarean sections in posterior pregnancies when the first labor is also through cesarean - it also increases the chances of placental complications. 17

The low rate of childbirth in private hospitals (5.4\%) among Brazilian adolescents in comparison to the total population $(19.9 \%)^{17}$ points towards the unfavorable socioeconomic conditions of this age group. Furthermore, there were inequalities among the adolescents, themselves, since white puerperal adolescents, who have health insurance and adequate schooling, registered the highest chance of having a surgical childbirth. Cesarean sections are closely related to higher chances of having a surgical childbirth - just for the record, cesarean sections are closely related to better socioeconomic conditions. 1

Rede Cegonha (Stork Network) recommends not to conduct episiotomy during vaginal childbirth, except for situations when it is really indicated, 29 since this intervention contributes to severe perineal lacerations $(\mathrm{OR}=3.82 ; \mathrm{CI} 95 \%=1.96-7.42)$. These lacerations are associated with the first pregnancy of most adolescents $(\mathrm{OR}=3.24$; CI95\% $=2.20-4.76)$, as shown in the results of a meta-analysis carried out in an international research. ${ }^{30}$ However, the scientific literature highlights that by using good practices during childbirth in hospitals, one can observe a reduced number of episiotomies; 29 thus, it improves the recovery and the perception about the vaginal childbirth experience.

Despite the wide range of collected data, this study presents some limitations. The time spent for data collection (2011-2012) and the exclusion of hospitals registering less than 500 births/year. However, the highlights are: the first national study based on obstetric and perinatal data, which allows a wide panorama about labor and births in Brazil; it covers all the Brazilian States and represents 2,337,475 births, $80 \%$ of them between 2011 and 2012. Moreover, puerperal adolescents represented almost $20 \%$ of the national sample, including public, private and mixed hospitals.

It is noteworthy that motherhood in adolescence does not occur in a homogeneous way, it is almost exclusive phenomenon to the low-income class women, which affects in being behind in schooling and do not have the intention to get pregnant. This study also stands out for the herein assessed age groups; the 12-16 years old age group registered the highest socioeconomic vulnerability, prenatal care and neonatal childbirth complication rates. This finding points out the need of multi-professional and specialized care for these adolescents.

The specificity of pregnant adolescents must be taken into consideration by health professionals in prenatal care, childbirth and puerperal care services; in other words, they must take into account their needs, be empathetic to them and build a bond relationship based on trust and affection. It is recommended for pregnant adolescents to find family support since the very beginning of their pregnancy in order to increase adhesion of prenatal care and the likelihood of having a safer childbirth.

Finally, scientific evidence must be taken into consideration at the time to elaborate sexual and reproductive health policies focused on adolescents, with emphasis on high-quality comprehensive sexual education since the early ages. Unplanned pregnancy prevention campaigns must be properly dialogued with the healthcare reality in Brazil, mainly with adolescents presenting higher social vulnerability.

\section{Authors' contribution}

Assis TSC: conception, planning, analysis, interpretation of the results and manuscript writing. Martinelli KG, Santos Neto ET and Gama SGN: conception, planning, interpretation of the results and final review of the manuscript. All authors have approved the final version of the manuscript. 


\section{References}

1. Gama SGN da, Viellas EF, Schilithz AOC, Theme Filha MM, Carvalho ML de, Gomes KRO, Costa, MCO, Leal MC. Fatores associados à cesariana entre primíparas adolescentes no Brasil, 2011-2012. Cad Saúde Pública. 2014; 30 (suppl. 1): S117-S127.

2. Santos MMA de S, Baião MR, Barros DC de, Pinto A de A, Pedrosa PLM, Saunders C. Estado nutricional pré-gestacional, ganho de peso materno, condições da assistência pré-natal e desfechos perinatais adversos entre puérperas adolescentes. Rev Bras Epidemiol. 2012; 15 (1): 143-54.

3. OMS (Organização Mundial da Saúde). [www.who.int]. Taxa de gravidez na adolescência no Brasil está acima da média latino americana e caribenha [acesso 9 nov 2019]. Disponível em: https://nacoesunidas.org/taxa-de-gravidezadolescente-no-brasil-esta-acima-da-media-latino-americana-e-caribenha/

4. Brasil. Ministério da Saúde. DATASUS. Informações de saúde. Sistema de informações sobre nascidos vivos. In: DATASUS [Internet]. Brasília, DF; 2018 [citado 2020 Jul 10]. Disponível em: http://tabnet.datasus.gov.br/cgi/ tabcgi.exe?sinasc/cnv/nvuf.def

5. Gibbs CM, Wendt A, Peters S, Hogue CJ. The Impact of Early Age at First Childbirth on Maternal and Infant Health. Paediatr Perinatal Epidemiol. 2012; 26: 259-84.

6. Domingues RMSM, Viellas EF, Dias MAB, Torres JA Theme-Filha MM, Gama SGN, et al. Adequação da assistência pré-natal segundo as características maternas no Brasil. Rev Panam Salud Publica. 2015; 37 (3):140-7.

7. Ganchimeg T, Ota E, Morisaki N, Laopaiboon M, Lumbiganon P, Zhang J, Yamdamsuren B, Temmerman M, Say L, Tunçalp Ö, Vogel JP, Souza JP, Mori R; WHO MulticountrySurveyon Maternal Newborn Health Research Network. Pregnancy and childbirth outcomes among adolescent mothers: a World Health Organization multicountry study. BJOG. 2014; 121 (Suppl. 1):40-8.

8. Tuon RA, Ambrosana GMB, Vidal e Silva SMC, Pereira AC. Impacto do monitoramento telefônico de gestantes na prevalência da prematuridade e análise dos fatores de risco associados em Piracicaba, São Paulo, Brasil. Cad Saúde Pública. 2016; 32 (7): e00107014.

9. Almeida, AHV de. Gravidez e parto em adolescentes no Brasil: desigualdades raciais e socioeconômicas na assistência pré-natal e associação com nascimento prematuro [tese]. Rio de Janeiro: Escola Nacional de Saúde Pública Sergio Arouca, Fundação Oswaldo Cruz; 2018.

10. Azevedo WF, Diniz MB, Fonseca ES, Azevedo LM, Evangelista CB. Complicações da gravidez na adolescência: revisão sistemática da literatura. Einstein. 2015; 13 (4): 618-26.

11. Grønvik T, Sandøy IF. Complications associated with adolescent childbearing in Sub-Saharan Africa: A systematic literature review and meta-analysis. PLoS ONE. 2018 13 (9): e0204327.

12. Santos NLAC, Costa COM, Amaral MTR, Vieira GO, Bacelar EB, Almeida AHV. Gravidez na adolescência: análise de fatores de risco para baixo peso, prematuridade cesariana. Ciênc Saúde Coletiva. 2014; 19 (3): 719-26.
13. Vasconcellos MTL, Silva PLN, Pereira APE, Schilithz AOC, Souza Junior PRB, Szwarcwald CL. Desenho da amostra Nascer no Brasil: Pesquisa Nacional sobre Parto e Nascimento. Cad Saúde Pública. 2014; 30: S49-58.

14. Leal MC, Silva AAM, Dias MAB, Gama SGN, Rattner D, Moreira ME, Theme Filha MM, Domingues RM, Pereira AP, Torres JA, Bittencourt SD, D'orsi E, Cunha AJ, Leite AJ, Cavalcante RS, Lansky S, Diniz CS, Szwarcwald CL. Birth in Brazil: national survey into labour and birth. Reprod Health. 2012; 9 (1): 15.

15. Chan AW, Pristach EA, Welte JW, Russell M. Use of the TWEAK test in screening for alcoholism/heavy drinking in three populations. Alcohol Clin Exp Res. 1993; 17 (6): 1188-92.

16. Brasil. Ministério da Saúde. Protocolos da Atenção Básica: Saúde das Mulheres / Ministério da Saúde, Instituto SírioLibanês de Ensino e Pesquisa. Brasília, DF; 2016

17. Nakamura-Pereira M, do Carmo Leal M, Esteves-Pereira AP, Domingues RM, Torres JA, Dias MA, Moreira ME. Use of Robson classification to assess cesarean section rate in Brazil: the role of source of payment for childbirth Reprod Health. 2016; 13(Suppl. 3): 128.

18. Zangiacomi Martinez E, da Roza DL. Ecological analysis of adolescent birth rates in Brazil: Association with Human Development Index. Women Birth. 2020; 33 (2): e191e198.

19. Nascimento TLC, Teixeira CSS, Anjos MS, Menezes GMS, Costa MCN, Natividade MS. Fatores associados à variação espacial da gravidez na adolescência no Brasil, 2014: estudo ecológico de agregados espaciais. Epidemiol Serv Saúde. 2021; 30 (1): e201953.

20. Vieira CL, Flores PV, Camargo KR, Pinheiro RS, Cabral CS, Aguiar FP, Coeli CM. Rapid Repeat Pregnancy in Brazilian Adolescents: Interaction between Maternal Schooling and Age. J Pediatr Adolesc Gynecol. 2016; 29 (4): $382-5$.

21. Miura PO, Tardivo LSLPC, Barrientos DMS, Egry EY, Macedo CM. Adolescence, pregnancy and domestic violence: social conditions and life projects. Rev Bras Enferm. 2020; 73 (Suppl. 1): e20190111.

22. Honório-França AC, Cardoso APM, França EL, Ferrari CKB. Gestação precoce e reincidência de gestações em adolescentes e mulheres de uma Unidade de Estratégia de Saúde da Família. Rev APS. 2013; 16 (2): 129-35.

23. Chirwa-Kambole E, Svanemyr J, Sandøy I, Hangoma P, Zulu JM. Acceptability of youth clubs focusing on comprehensive sexual and reproductive health education in rural Zambian schools: a case of Central Province. BMC Health Serv Res. 2020; 20 (42)

24. Glynn JR, Sunny BS, DeStavola B, Dube A, Chihana M, Price AJ, Crampin AC. Early school failure predicts teenage pregnancy and marriage: A large population-based cohort study in northern Malawi. Plos One. 2018; 13 (5): $\mathrm{e} 0196041$.

25. Mehra D, Sarkar A, Sreenath P, Behera J, Mehra S. Effectiveness of a community based intervention to delay 
early marriage, early pregnancy and improve school retention among adolescents in India. BMC Public Health. 2018; 18 (732).

26. Marvin-Dowle K, Kilner K, Burley VJ, Soltani H. Impact of adolescent age on maternal and neonatal outcomes in the Born in Bradford cohort. BMJ Open. 2018; 8: e016258.

27. Lopes MCL, Oliveira RR, Silva MAP, Padovani C, Oliveira NLB, Higarashi IH. Temporal trend and factors associated to teenage pregnancy. Rev Esc Enferm USP. 2020; 54:e03639.
28. Leal MC, Bittencourt SD de A, Torres RMC, Niquini RP, Souza Jr PRB de. Determinants of infant mortality in the Jequitinhonha Valley and in the North and Northeast regions of Brazil. Rev Saúde Pública. 2017; 51 (12).

29. Medeiros RMK, Teixeira RC, Nicolini AB, Alvares AS, Corrêa ACP, Martins DP. Humanized Care: insertion of obstetric nurses in a teaching hospital. Rev Bras Enferm. 2016; 69 (6): 1029-36

30. Pergialiotis V, Vlachos D, Protopapas A, Pappa K, Vlachos G. Risk factors for severe perineal lacerations during childbirth. Int J Gynaecol Obstet. 2014; 125 (1): 6-14.

Received on September 30, 2020

Final version presented on May 11, 2021

Approved on August 28, 2021 